\title{
Community, commons, and degrowth at Dancing Rabbit Ecovillage
}

\author{
Joshua Lockyer $^{1}$ \\ Arkansas Tech University, USA
}

\begin{abstract}
For centuries, intentional communities of various sorts have been formed to experiment with alternative socio-cultural and economic models. As we enter the Anthropocene and find ourselves in a world challenged to create a post-carbon economy that is no longer reliant on endless growth, such models are in greater demand than ever. Since the mid-1990s, hundreds of ecovillages around the world have been experimenting with ways to achieve prosperity without growth. Linking to three transition discourses, this article uses ongoing ethnographic research to describe how one intentional community - Dancing Rabbit Ecovillage in northeast Missouri, USA - is forging such models by cultivating cooperative cultural values and behaviors, recreating the commons, and sharing their experiences and lessons with broader publics through media, research, and educational programs. Based on ongoing participatory action research, I present data on areas such as energy use, water use, solid waste production, and perceived happiness to illustrate that the community is achieving the decreased consumption patterns required for degrowth while maintaining a high quality of life for its members. Finally, the paper reflects on the role of the activist-researcher facing the dual tasks of helping the community move toward its goals while simultaneously translating the particular to more broadly applicable theory and practice.
\end{abstract}

Key words: commons, degrowth, ecovillages, intentional communities, participatory action research, transition discourses

\section{Résumé}

Pendant des siècles, les communautés intentionnelles de toutes sortes ont été créées pour expérimenter avec des modèles socio-culturels et économiques alternatives. Comme nous entrons dans l'anthropocène et nous nous trouvons dans un monde mis au défi de créer une économie post-carbone qui n'est plus dépendante à une croissance sans fin, ces modèles sont plus sollicités que jamais. Depuis la moitié des années 1990, des centaines d'éco-villages à travers le monde ont essayés de parvenir à la prospérité sans croissance. En faisant la liaison de trois discours de transition différents, cet article utilise une recherche ethnographique en cours pour décrire la façon dont une communauté intentionnelle Dancing Rabbit Ecovillage dans le nord du Missouri, au États-Unis - forge de tels modèles qui cultivent les valeurs et les comportements culturels coopératifs, recréent des biens communs, et partagent leurs expériences et ces leçons avec un public plus large à travers les médias, les recherches, et les programmes éducatifs. En se basant sur les recherche-actions participatives en cours, je présente des données sur des domaines tels que la consommation d'énergie, l'utilisation de l'eau, la production de déchets solides, et le bonheur perçu pour illustrer que la communauté moins (nécessaire pour le décroissance)

\footnotetext{
1 Dr. Joshua Lockyer, Associate Professor of Anthropology, Department of Behavioral Sciences, Arkansas Tech University, Russellville, AR 72801, USA. Email: jlockyer "at" atu.edu. The author would like to acknowledge the contributions to this paper of K. Brooke Jones without whose ongoing collaboration, data collection for this article would not have been possible. Carlina Arango, Morgan Middlebrooks, and Kyle Manning also provided assistance with data collection. Lisa Gezon and Susan Paulson provided valuable feedback on earlier drafts and I thank them for organizing the AAA panel on 'Culture, Power, and Degrowth' out of which this article emerged. Research was kindly supported by the Center for Social Development, George Warren Brown School of Social Work at Washington University in St. Louis; the Faculty Research Grant Office of Academic Affairs at Arkansas Tech University; and a Small Grant for Collaborative Problem Solving from the Anthropology and Environment Society of the American Anthropological Association. Additional funding came from the Center for Prairie Studies at Grinnell College and anonymous donors to the Center for Sustainable and Cooperative Culture, a 501(c)3 nonprofit organization that is DR's research and education wing. This is the sixth article in Lisa L. Gezon and Susan Paulson (eds.) 2017. "Degrowth, culture and power", Special Section of the Journal of Political Ecology, 24: 425-466.
} 
tout en maintenant une qualité de vie élevée pour ses membres. Enfin, ce document réfléchit sur le rôle des activistes-rechercheurs face à la double tâche d'aider le mouvement communautaire dans leurs objectifs tout en traduisant simultanément ces particuliers à une théorie et une pratique plus largement applicable.

Mots clés: biens communs, la décroissance, les écovillages, les communautés intentionnelles, la rechercheaction participative, les discours de transition

\section{Resumen}

Durante siglos, se han formado comunidades intencionales de varias clases para experimentar con modelos socio-culturales y económicos alternativos. Al entrar en el Antropoceno nos encontramos en un mundo lleno de desafíos para crear una economía post-carbono que ya no es dependiente de crecimiento sin fin, estos modelos están en mayor demanda que nunca. Desde mediados de la década de 1990, cientos de ecoaldeas alrededor del mundo han estado experimentando con formas de lograr la prosperidad sin crecimiento. Al vincularse a tres discursos de transición, este artículo utiliza la investigación etnográfica en curso para describir cómo una comunidad intencional - Dancing Rabbit Ecovillage en el noreste de Missouri, EE.UU. forja tales modelos mediante el cultivo de valores culturales y comportamientos de cooperación y, la recreación de los comunes., yMuestra como comparten sus experiencias y lecciones con públicos más amplios a través de los medios de comunicación, la investigación y los programas educativos. Basáandome en la investigación de acción participativa en curso, presento datos sobre áreas tales como el uso de energía, el uso del agua, la producción de residuos sólidos, y la felicidad percibida para ilustrar que la comunidad está logrando los patrones de consumo disminuido necesarios para el decrecimiento y a su vez mantiene una alta calidad de vida para su miembros. Por último, el artículo reflexiona sobre el papel del investigador activista que enfrenta la doble tarea de ayudar al movimiento de la comunidad hacia sus objetivos y simultáneamente a traducir lo particular a una teoría y práctica más ampliamente aplicable.

Palabras clave: bienes comunes, el decrecimiento, ecoaldeas, comunidades intencionales, la investigación de acción participativa, los discursos de transición

\section{Introduction}

In this article, I locate the convergence of three 'transition discourses' in the collective endeavors of community members at Dancing Rabbit Ecovillage (DR) in rural, northeast Missouri. Transition discourses are paradigmatic calls for civilizational transformation manifested in a variety of grassroots actions and arising from recognition of the injustice and unsustainability of predominant socio-cultural configurations (Escobar 2015). According to Escobar, transition discourses share "the contention that we need to step out of existing institutional and epistemic boundaries if we truly want to envision the worlds and practices capable of bringing about the significant transformations seen as needed" for a more just and sustainable future (Escobar 2015: 452). Thus, many transition discourses are counter-narratives to the ideologies that promote the continued spread and global dominance of growth-based, industrial, consumer capitalism.

The three transition discourses that I focus on - degrowth, the commons, and intentional community are each characterized by diversity of action on the part of activists as well as significant multidisciplinary academic engagement and analysis from a variety of different angles. Growing bodies of scholarship and material outcomes demonstrate: a) the foolhardiness of continuing to follow the path of growth-based economic development as a route to wellbeing on a finite planet (Jackson 2009); and b) the positive potential of practical initiatives grounded in all three discourses for addressing the problem of unsustainable growth (see Latouche 2009; Lockyer and Veteto 2013 and Ostrom et al. 2002). Using my research on and collaboration with DR, I demonstrate the achievements of an intentional community founded on common property arrangements and point to the potential it holds for modeling some effective strategies for economic degrowth. I conclude this article by arguing for increased collaboration among activist practitioners of transition discourses and engaged scholars concerned with a degrowth perspective and the normative issues of justice and sustainability inherent in it.

\section{Three transition discourses: intentional communities, the commons, and degrowth}

Over the past three centuries, economic growth has been achieved in part through the enclosure of the commons and the replacement of functioning local communities with bounded individual consumers and 
households, each pitted against another in pursuit of ever-increasing accumulation of wealth and material goods. During the rise of growth-based, industrial, consumer capitalism, and arguably in order to marginalize anything other than a growth-based order, common property arrangements and any deliberate attempts to construct social alternatives have been derisively labelled as foolishly romantic, impractical endeavors. Common property institutions and community-based cooperation are often depicted as relics of a preindustrial past, unrealistic 'utopian' pursuits not worthy of serious consideration (see Bollier 2014 for an overview of dismissive narratives of the commons, and Sargisson 2012a for a useful review of contrasting positive and negative uses and connotations of the term 'utopian'). But the advent of the Anthropocene - the proposed new geologic epoch during which human activities are recognized as having potentially catastrophic impact equivalent to major geophysical forces - challenges us to reconsider the value and meaning of the term 'utopian' and of social endeavors designated as such, especially if the Anthropocene is seen as signifying the potential end of conditions that allowed human flourishing (Stefan, Crutzen, and McNeill 2007). In this context, the continuation of growth-based, industrial, consumer capitalism becomes an unrealistic pursuit unworthy of further support, while 'utopian' efforts to recreate human organization take on new urgency and relevance. Deliberately rebuilding local communities, recreating commons arrangements, and seeking paths to enhanced well-being and economic degrowth become prefigurative utopian endeavors inherently valuable projects in the 'reconstitution of society' (Levitas 2013).

\section{Degrowth}

Degrowth has emerged as a transition discourse in the last two or three decades and, as this Special Section of the Journal of Political Ecology demonstrates, is a growing area of engagement between activists and scholars (Paulson 2017). Proponents of degrowth argue that the current world situation challenges us to create a post-carbon economy that sheds the presumed requirement for endless economic growth as a precondition for progress and, simultaneously, manifests the conditions for human well-being. According to Jackson (2009: 2), "[o]ur technologies, our economy, and our social aspirations are all mis-aligned with any meaningful expression of prosperity. The vision of social progress that drives us - based on the continual expansion of material wants - is fundamentally untenable. ... In pursuit of the good life today, we are systematically eroding the basis for well-being tomorrow." Yet growth - in material and energy throughput and in the accumulation of private, individual wealth and consumer goods - has been and continues to be the foundation of modern, industrial capitalism. The concept of economic growth is a foundational logic that guides economic and social activity; material growth is the practical means of 'progress' in the industrial, consumer political economy.

Jackson goes on to point out that changes in both cultural logic and the structures of industrial, consumer capitalism are required to address the dilemma of growth: "[t]he first will be to dismantle or correct the perverse incentives for unsustainable (and unproductive) status competition. The second must be to establish structures that provide capabilities for people to flourish, and particularly to participate fully in the life of society, in less materialistic ways" (Jackson 2009:153). From Jackson's perspective, the path to degrowth requires creating venues wherein fundamental shifts in cultural logic can be manifested in social and economic life. Building on Jackson's perspective, Latouche points out that the degrowth project is inherently, and positively, utopian in nature:

Outlining the contours of what a non-growth society might look like is an essential preliminary to any programme for political actions that respects the ecological demands of the moment. The de-growth project is therefore a utopia, or in other words a source of hope and dreams. Far from a flight into fantasy, it is an attempt to explore the objective possibility of its implementation (Latouche 2009: 32).

Accepting the utopian character of the degrowth challenge is an essential first step toward addressing it, but the question remains as to whether and where such utopian models for degrowth are being created.

\section{The commons}

One area in which practical experiments resonating with degrowth discourse have emerged is a growing collection of projects aimed at resurrecting longstanding patterns of common property resource 
management that have drawn intensive scholarly interest over recent decades. Going against the tremendous and continuing influence of Hardin's arguments in "The Tragedy of the Commons" (Hardin 1968), growing recognition (including a Nobel Prize in economic sciences) has been granted to the counter-arguments and evidence offered by Elinor Ostrom and a great number of other analysts of common property resource arrangements (Burger et al. 2001; Dolšak and Ostrom 2003; Donahue 1999; McCay and Acheson 1987; Ostrom et al. 2002; Nonini 2008). These scholars have effectively demonstrated that communities of people have developed and utilized their own systems of cultural norms and rules to sustainably manage resources over the long term in the absence of private property or top down government intervention. They have also identified certain conditions that support successful and sustained commons management.

In parallel and often drawing on the work of Ostrom and other scholars, much activism has been undertaken in defense of existing commons, especially where those commons are threatened by encroachment from neoliberal regimes in a "tragedy of enclosure" (see Martinez-Alier et al. 2014 and Escobar 2015). Defense of the commons has been manifested in a variety of forms including resistance to the privatization of democratically controlled public water systems in Bolivia (Dwinell and Olivera 2014), challenges to 'land grabs' by foreign governments and multinational corporations in Africa (Alden Wiley 2011), and resistance to the patenting of genetic diversity and associated local knowledge (Kloppenburg 2010). Many but not all of these projects are centered in the Global South and include significant concerns about social and environmental justice.

Commons activism has also focused on efforts to create and/or recreate common property arrangements or what is often referred to as acts of 'commoning' as a "vehicle for social and political emancipation and societal transformation" (Bollier 2014: 2). In this view, the act of 'commoning' serves as a counter to the individualist accumulation wealth and goods that drives the growth economy. Examples of such commoning endeavors, often but not always anchored in the Global North, include efforts to build open source and open access digital commons, open source designs for useful tools and technologies, the construction of lending libraries for tools and seeds, and intentional community building (see Bollier 2014).

\section{Intentional communities}

Deliberately formed communities have long been a context for experimenting with social alternatives and scholars have outlined a history of intentional communities stretching back thousands of years (Metcalf 2004; Pitzer 1997a). Since well before industrial times, people have repeatedly and deliberately come together to form local communal societies to experiment with alternative socio-cultural and economic forms. Concerns about the social injustices associated with the early expansion of industrial capitalism were clearly expressed in the form of intentional communities. Robert Owen's worries about the plight of poor industrial workers led him to establish a number of planned communities in the early 1800s, most notably New Lanark in Scotland and New Harmony in Indiana, United States, in an effort to "achieve abundance for all and thus the disappearance of private property and social inequality" (Pitzer 1997b:98). During the latter half of the nineteenth century, followers of the French political philosopher Etienne Cabet engaged in five separate attempts to create the ideal community that he envisioned. According to Sutton, the Icarians, as they were known, "believed that personal salvation lay in a community of brotherly love. They saw two steps to achieving salvation: renouncing the sins of capitalism, and participation in a spiritual regeneration of selflessness in a democratic utopia where each gave according to ability and need" (1997: 288). In the $20^{\text {th }}$ century, the American engineer and educational reformer Arthur Morgan founded Celo Community in North Carolina based on his interest in the small community as the fundamental unit of human cultural evolution and his "belief that the integrity of the small community was threatened by the development of modern, industrial society" (Lockyer 2007: 28). Morgan also went on to help found the Fellowship of Intentional Communities (forerunner of today's Fellowship for Intentional Community) as an organization to support the proliferation of intentional community building endeavors in the United States.

More recently, concerns about ecological damages and environmental justice have come to the forefront of intentional community building with the emergence of ecovillages, cohousing communities, transition towns and other sustainability-oriented communal projects. According to Lockyer and Veteto 
(2012: 92), ecovillagers attempt to live in ways that reduce the patterns of social and environmental injustice resulting from uneven distribution of resources and resource use among rich and poor on both local and global levels. Ecovillagers are essentially trying to internalize what economists refer to as externalities; they recognize that in a global economy the processes of production and consumption produce far-flung social and environmental consequences that are not accounted for in the costs of things they consume. They are attempting to make these costs more visible by bringing production and consumption processes within a more local sphere (see also Litfin 2014, Lockyer and Veteto 2013).

The cooperative management of shared resources has been the foundation of many intentional communities; all of the communities discussed in the paragraph above - New Lanark, New Harmony, the Icarias, and Celo Community - were based on forms of common property holding. The ecovillagers discussed in this article have built their community on a form of collective landholding and communal resource management facilitated by the land trust model (see below). Other intentional community building endeavors such as cohousing communities aim to reduce their members' negative impact on people and the planet by substituting common property in the form of shared walls, utilities, and recreation space, for private property in the form of distinctly bounded individual households (see Lockyer 2010a, 2010b). Studies have shown that such communities have increased social capital and perceived satisfaction with life while decreasing material consumption (Mulder, Costanza, and Erickson 2006).

\section{Dancing Rabbit Ecovillage}

Dancing Rabbit Ecovillage is a contemporary manifestation of intentional community building and a hub of international intentional community networking. DR is a home base of the Fellowship for Intentional Community (FIC), "a nonprofit organization dedicated to promoting cooperative culture" (Fellowship for Intentional Community 2015a). The FIC spearheads a number of endeavors including maintaining a website, hosting a database of contemporary intentional communities worldwide, and publishing a quarterly magazine called Communities: Life in Cooperative Culture. In the front matter of every issue of Communities magazine, the FIC publishes a definition of intentional community that clearly establishes the movement and its constituents as a transition discourse:

An "intentional community" is a group of people who have chosen to live or work together in pursuit of a common ideal or vision. Most, though not all, share land or housing. Intentional communities come in all shapes and sizes, and display amazing diversity in their common values, which may be social, economic, spiritual, political, and/or ecological. Some are rural; some urban. Some live all in a single residence; some in separate households. Some raise children; some don't. Some are secular, some are spiritually based; others are both. For all their variety, though, the communities featured in our magazine hold a common commitment to living cooperatively, to solving problems nonviolently, and to sharing their experiences with others (Fellowship for Intentional Community 2015b: 6).

The FIC database currently has listings for over 2,500 intentional communities worldwide (Fellowship for Intentional Community 2015c), demonstrating that this is a movement and a discourse with significant transformative, transitional potential across cultural contexts.

Dancing Rabbit Ecovillage includes approximately 65 people located on 280 acres of recovering industrial farmland in rural northeast Missouri, USA (Figure 1). ${ }^{2}$ DR was founded in the mid 1990s when a

\footnotetext{
${ }^{2}$ Identifying the precise number of members in any intentional community is notoriously difficult. Many intentional communities have a formal process, often lasting up to a year, through which existing and potential community members get to know each other and flesh out common understandings about the nature of their endeavor to ensure mutual compatibility. At the same time, some full community members may not currently reside in the community while retaining community membership. Thus, in addition to full community members, many people who are resident in the community are only in a position of exploring membership even as that process of exploring is a significant commitment. Thus, the number I have given here represents approximately 35 out of 40 full community members who live on the community's land plus another 30 or so people who are in the process of exploring membership.
} 
group of graduate students from a student co-op at Stanford University decided to move beyond protesting ecological destruction and begin taking concrete actions. ${ }^{3}$ The group met regularly, took steps to attract additional participants, and began exploring the lessons provided by historic and contemporary intentional communities. The commitment to experiment with alternative, more sustainable socio-cultural and economic forms and share the lessons learned is clear from DR's mission statement:

To create a society, the size of a small town or village, made up of individuals and communities of various sizes and social structures, which allows and encourages its members to live sustainably. To encourage this sustainable society to grow to have the size and recognition necessary to have an influence on the global community by example, education, and research (Dancing Rabbit Ecovillage 2015a).

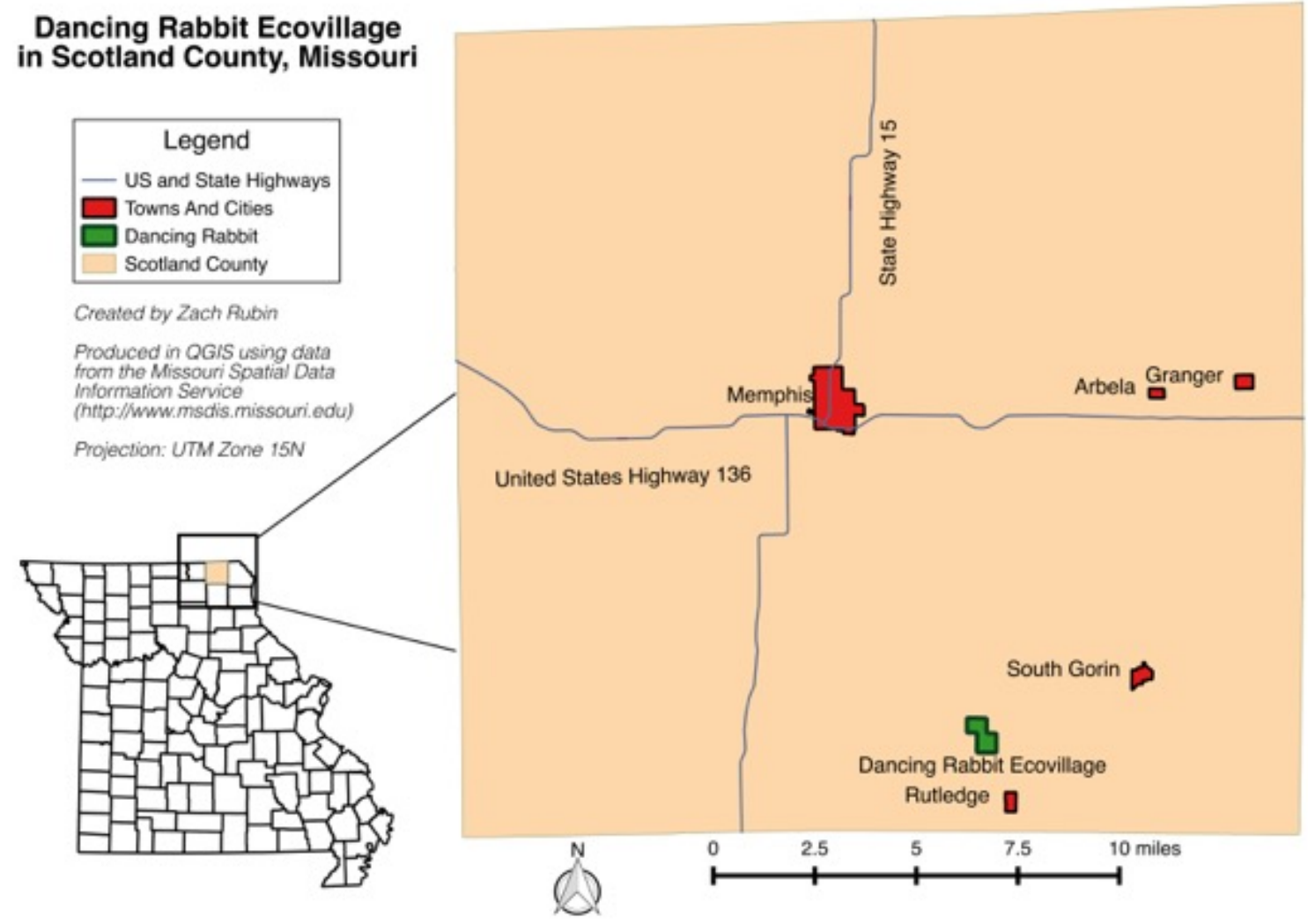

Figure 1: Dancing Rabbit Ecovillage location map. Source: Zach Rubin 2015.

In pursuit of this mission, DR's founders purchased 280 acres (113 ha) in rural northeast Missouri and set about building their initial structures and recruiting additional community members. ${ }^{4}$ From the outset,

\footnotetext{
${ }^{3}$ Identifying the precise founding dates for intentional communities is also notoriously difficult. For example, is the founding identified as the year in which concrete plans were laid? Is it the year during which the land or other property where the community exists was purchased? Or is it the year during which people actually began to live on the land? For this reason, I have chosen 'the mid-1990s' as the founding date because it encapsulates all of these activities for DR.

${ }^{4}$ The founders chose this location for at least two specific reasons. First, they recognized that policies such as zoning and building codes would, in many places, restrict them from engaging in the kinds of experiments that they wished to
} 
DR's founders chose to base their endeavor on a number of common property resource arrangements. For example, all DR members are part of a collective body that owns and manages their infrastructure including roads, paths, and common buildings (one of the first buildings they constructed is to this day called 'the common house'). Some members are part of smaller cooperatives that own and manage services such as showers, laundry, internet access, and utilities. In addition, one of the conditions of community membership (more on these conditions below), is that community members may not keep a personal automobile on common land for regular use. Instead, DR has established a vehicle coop whereby all community members share the ownership, use, and maintenance of four vehicles. ${ }^{5}$

Perhaps the most fundamental act of commoning at DR is the establishment of a land trust model of landholding governed through a process of collective planning and decision making. In this endeavor, DR's collective desire to break with individualized, growth based models of wealth accumulation is clear and explicit:

The land trust model takes land out of the speculative market while still providing an ownership-like option for our members. Each individual or household can lease a small plot of land for a monthly fee. ...Leaseholders do not own their land, but do own any improvements on their land including any buildings, orchards, gardens, etc. These can be sold to another member if someone leaves the community or moves to a different leasehold. Since members can't sell their land, there is no ability to speculate and land can be a permanently affordable resource at Dancing Rabbit (Dancing Rabbit Ecovillage 2015b).

Further, each leasehold, leased from the larger collective of which the lessee is part, is developed through a collaborative ecological design process:

Each new leasehold must go through a community approval process. The community attempts to guide new members through an ecological design process to make sure they are taking into account both the needs of their household or garden and the effects it will have on their neighbors and our land. Our goal is to allow great flexibility for each member to realize their vision of a sustainable dwelling or garden while also fitting their goals into the larger design goals of the village (Dancing Rabbit Ecovillage 2015b).

All of this is overseen through a system of collective governance. As the community's population has grown, its governance system has evolved from full group consensus decision making to a representative village council within which decisions are made by consensus and sometimes delegated to committees. In addition, the community reserves several days a year for a retreat where all community members gather to discuss and update community issues including the community's relationship with its land. The overall goal is to give community members ample opportunity to participate actively in governing commonly held resources.

When one lives on 280 acres of land whose ownership one shares with dozens of other people and when one shares four vehicles with those same dozens of other people, one's life is quite different from life in the suburbs or exurbs of America. Being enmeshed in the commons is not compatible with actions motived primarily by the pursuit of personal gain that drives the growth economy. Instead, one is bound by a set of agreed upon values that reflect the intents of the larger group endeavor. In the case of DR, these values

undertake. These restrictive conditions were absent in rural Missouri. Second, another intentional community, Sandhill Farm, had been established in the 1970s on a parcel of land a few miles away and the founders wished to draw on the knowledge and experience of the members of that community so as to avoid wasting time and energy completely reinventing the wheel of intentional community.

${ }^{5}$ DR members have also created a community currency called ELMs that can be conceptualized as a form of commons. Alternative currencies have been identified as essential alternatives to the banking system that lies at the heart of growthbased, industrial, consumer capitalism (see North 2005). This act of commoning at DR is beyond the scope of this paper. 
include the stewardship of their land and other common property resources described above. In addition, DR's creation of the local commons has manifested a socio-cultural context and logic within which the cultural value shift required to manage commons at much larger scales has also been cultivated. This orientation to both local and global commons is manifested in the community's codified lists of 'ecological covenants' and 'sustainability guidelines' (Figures 2 and 3):

1. Dancing Rabbit members will not use personal motorized vehicles, or store them on Dancing Rabbit property.

2. At Dancing Rabbit, fossil fuels will not be applied to the following uses: powering vehicles, spaceheating and -cooling, refrigeration, and heating domestic water.

3. All gardening, landscaping, horticulture, silviculture and agriculture conducted on Dancing Rabbit property must conform to the standards as set by OCIA [Organic Crop Improvement Association] for organic procedures and processing. In addition, no petrochemical biocides may be used or stored on DR property for household or other purposes.

4. All electricity produced at Dancing Rabbit shall be from sustainable sources. Any electricity imported from off-site shall be balanced by Dancing Rabbit exporting enough on site, sustainably generated electricity, to offset the imported electricity.

5. Lumber used for construction at Dancing Rabbit shall be either reused/reclaimed, locally harvested, or certified as sustainably harvested.

6. Waste disposal systems at Dancing Rabbit shall reclaim organic and recyclable materials.

Figure 2: Dancing Rabbit Ecovillage 'Ecological Covenants'. Source: Dancing Rabbit Ecovillage 2015c http://www.dancingrabbit.org/about-dancing-rabbitecovillage/vision/ecological-covenants/.

- Dancing Rabbit will look holistically at the issues of sustainability to create a sustainable culture that takes into account all impacts of its actions and acts to preserve the Earth for the future.

- Dancing Rabbit will strive to rely only upon renewable resources, and to use them at a rate less than their replacement.

- Dancing Rabbit will try to understand and minimize its negative impact on global ecological systems.

- Dancing Rabbit will attempt to preserve and rebuild healthy ecosystems and have a positive impact on biodiversity.

- Dancing Rabbit will try to create a closed resource loop where byproducts are reintegrated as useful resources, thus attempting to minimize waste products, especially those toxic or radioactive.

- Dancing Rabbit will try to avoid exploiting people and other cultures.

- Dancing Rabbit will strive to achieve negative population growth from reproduction.

Figure 3: Dancing Rabbit Ecovillage 'Sustainability Guidelines'. Source: Dancing Rabbit

Ecovillage 2015d http://www.dancingrabbit.org/about-dancing-rabbit-

ecovillage/vision/sustainability-guidelines/.

These lists express DR's intention to reorient community members' basic economic practices and values in such a way that they may be effective stewards of local commons while also being responsible citizens of commons that are more global in scope. They point the way toward patterns of decreased resource consumption that, in the Global North at least, must be a component of any endeavor to achieve a degrowth society. It is with regard to some of the goals contained in these ecological covenants and sustainability guidelines that my collaborative research relationship with the DR community has taken root over the last six years. 


\title{
4. Evaluating progress toward sustainability at DR: methodology and results
}

\begin{abstract}
Some of the hardest moments for me are when spending time with friends and family who are not yet organizing their lives and all their daily choices around the most sustainable/lowest impact options at each juncture. I prefer to demonstrate rather than remonstrate, and there is only so far it feels reasonable to push my beliefs when in that company. Each disposable or even recyclable container or car trip I fail to avoid leaves me feeling that much heavier. How large already is the mountain of such impacts I have personally been responsible for in my life? (DR community member on DR's weekly blog The March Hare 2015; see http://www.marchhareblog.com)
\end{abstract}

I think it's real important that we do things like this [our collaborative research project] in order to measure our progress, to measure whether we're meeting our intentions. It gives us ideas on how we can go beyond what we are doing so far. Continual measurement is important. (Interview with DR community member, summer 2015)

This research project started with a conversation about meaningful, collaborative research. In the summer of 2010 following over a year of visiting DR and taking students there for field trips for my Environmental Studies and Intentional Communities classes, I sat down with DR community members for an official community 'salon' to discuss and envision how an academic research project could be meaningful to the community. We specifically sought ways to actively support the community as they work toward their goals. The community had long desired to have a way to measure the sustainability of their endeavors and had previously attempted to measure their impact using the popular ecological footprint index, but found that metric ineffective for their purposes. ${ }^{6}$ Community members asked us to help them assess their progress toward their goals, particularly of living ecologically sustainable and personally satisfying lives.

To facilitate this project we adopted a participatory action research (PAR) framework. PAR has a multidisciplinary history, having been employed broadly in anthropology, sociology, psychology, and education. Under the PAR rubric, helping communities achieve their goals is the driving force of research. In all of its incarnations, PAR is characterized by a number of common principles: attention to power inequalities both within society and between researcher and researched, active collaboration to empower communities with the capacity to create social change, a focus on community-driven research questions and methods, and an understanding of research as an ongoing, iterative process with the goal of improving social (and by extension ecological) conditions. Practitioners of participatory action research usually conceptualize themselves as advocates, making social science tools available to communities and collaborating with them to achieve social change, especially in marginalized, disenfranchised communities. ${ }^{7}$

While most members of ecovillages in the Global North are not from economically disadvantaged backgrounds, the communities they have chosen to help construct are often marginalized in mainstream discourses about justice and sustainability and have received little serious attention from scholars (for exceptions see: Kirby 2003; Litfin 2013; Lockyer and Veteto 2013; Sargisson 2012b; Trainer 2000, 2002; Van Schyndel Kaspar 2008). Having spent over a decade conducting ethnographic research within ecovillages, I often witnessed the difficulties faced by community members as they attempt to gain traction for their efforts with broader publics, policy makers, and environmental researchers. PAR allows us to produce community-driven data and knowledge that can help ecovillagers more effectively achieve goals and

\footnotetext{
${ }^{6}$ See Rees and Wackernagel (1998). Ecological footprint tools continue to evolve but in their early incarnations there were so many assumptions built into the measures that it was impossible to accurately reflect the behaviors and lifestyles of people in a place like DR. As our research project evolves, and as ecological footprinting tools become more nuanced, we are considering employing the tool in this project. For now, our data collection and analysis decidedly don't reflect the ecological footprint of DR.

${ }^{7}$ See Chambers (1997), Ervin (2000), Lambert-Pennington (2010) and LeCompte and Schensul (2010).
} 
communicate with the public about their work, while also opening windows on how communities and economies are being reconstructed as people seek greater justice, sustainability, and fulfillment in the world.

In the fall of 2012, I recruited a graduate student - K. Brooke Jones - who was seeking a site for her master's thesis research in applied anthropology at the University of North Texas. The policy for graduate research projects in that department stipulates that each project must serve the needs of a 'client' with whom the graduate student works to design the research. In collaboration with the other members of Jones's graduate committee, it was determined that helping DR assess their progress toward community goals was a good fit for her research. Following an academic year of literature review and project design (the latter in ongoing collaboration with the community), Jones arrived in DR during summer 2013 to begin the process of ethnographic immersion and data collection under my supervision and with assistance from two undergraduate students from my academic institution.

Following the PAR framework and in collaboration with DR's eco-progress committee, whose charge includes overseeing the community's alignment with its goal of ecological sustainability, we let community goals, definitions, guidelines and covenants guide our research design. During group conversations we focused on identifying components of the community's approach to sustainability that we could most easily measure and compare against existing data for the mainstream society to help assess the impact of ecovillage living. Our relatively limited resources and the need to simply start somewhere and build toward more robust research procedures also drove our research design process. Specific areas of data collection we chose to focus on included solid waste and recycling, number of vehicles per person, travel miles per person, vehicle fuel use, natural gas use, electricity use, water use, and perceived quality of life.

Subsequent to summer 2013, some data collection has been ongoing continuously, especially when data collection does not require a high number of on-the-ground researcher hours. For example, consumption of county water and natural gas are already tabulated by other organizations. On-site electricity production and consumption is monitored by community members themselves and, more recently following the connection of community wind and photovoltaic systems to the grid, by the local electric company. I also made occasional trips to the community during summer and fall 2014 and summer 2015 and Jones has subsequently moved to the community to take the position of Research Director with DR's nonprofit organization. Finally, in collaboration with DR's new Research Director and an undergraduate research intern from Grinnell College, we conducted another season of intensive data collection during summer and fall of 2015.

Our research team collected data on selected sustainability indicators in various ways with our limited resources. Research methods included review of existing records and community archives for natural gas and water consumption as well as local travel miles and vehicle fuel consumption, self-reporting by individual community members for some natural gas consumption and rainwater catchment, participant observation for general ethnographic context and data triangulation, individual interviews and surveys for perceived quality of life, and physical collection for solid waste and recycling. In the following, I elaborate on our data collection and analysis in each area.

\section{Data analysis and results}

Solid waste and recycling data was gathered through physical residential trash collection (Figure 4). Research team members provided door-to-door trash service for all community members who volunteered to participate in this portion of the project. This component of the research increased buy-in by community members who were generally happy to have this service provided while researchers took this opportunity to build further rapport with members of the community. Researchers weighed all solid waste and recyclables before disposing of them in the proper receptacles for pick up by municipal services. Our analysis of two seasons of data shows that participants produce roughly 0.2 pounds $(0.09 \mathrm{~kg})$ of solid waste per person, per day and roughly 0.6 pounds $(0.27 \mathrm{~kg})$ of recycling per person, per day, for a total of 0.8 pounds $(3.6 \mathrm{~kg})$ of total municipal solid waste per person, per day. DR members produce on average only $18 \%$ the amount of total municipal solid waste of the average American (United States Environmental Protection Agency 2015). Additionally, DR recycles at a rate of $73 \%$ of their total municipal solid waste produced compared to the 
average American's 34\%; that is over double the rate of recycling compared to the rest of the nation (United States Environmental Protection Agency 2015).

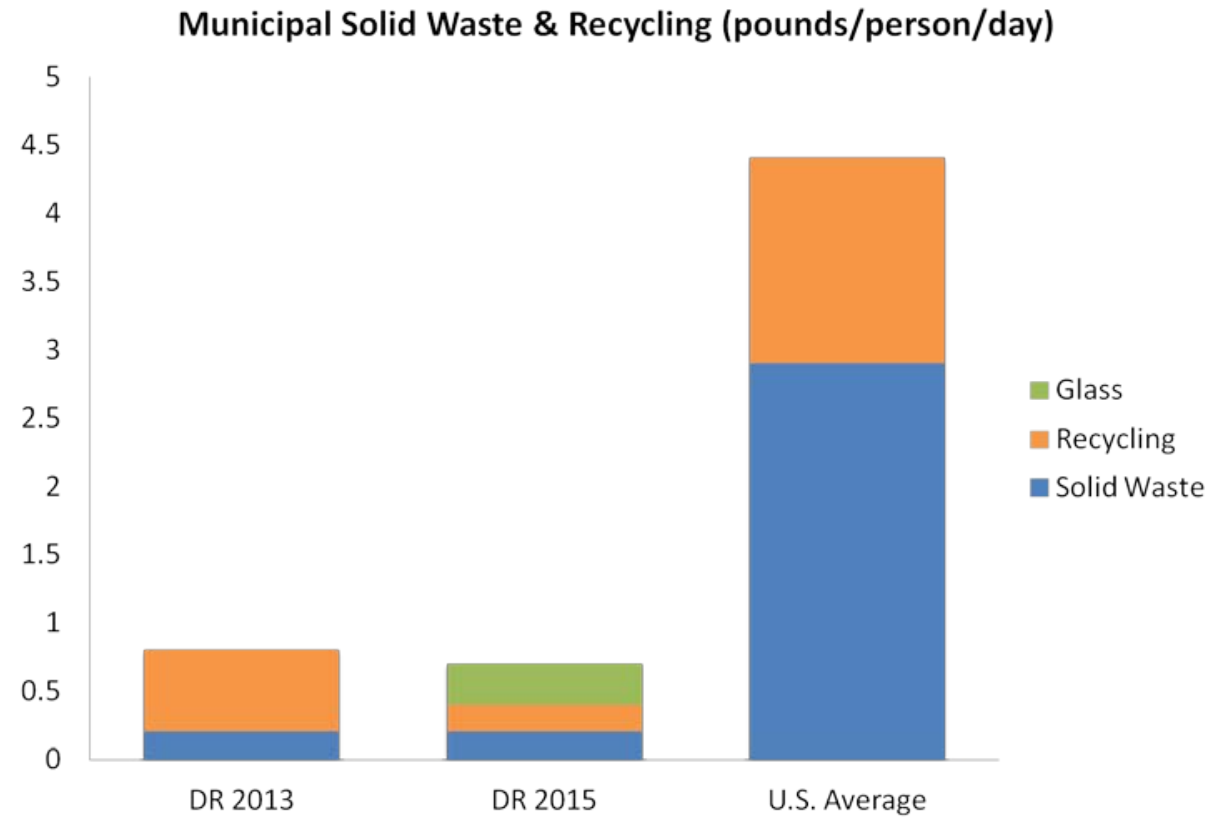

Figure 4: Dancing Rabbit solid waste and recycling production. Source: K. Brooke Jones 2015.

Number of vehicles per capita includes all vehicles owned and operated by the Dancing Rabbit Vehicle Coop (DRVC) divided by the total number of paying users (both drivers and passengers) (Figure 5). Since one of DR's ecological covenants states that community members may not use personal vehicles in their daily lives, most community members join the DRVC to have access to transportation. DRVC collects data on all vehicle miles traveled, by whom, and where, providing an abundant data source for this indicator. An average of 67 DRVC users were recorded for 2013 and 2014, sharing four vehicles. ${ }^{8}$ This means DR has 0.06 cars per capita which is $8 \%$ the US per capita rate, or $92 \%$ less than the average American rate of 0.8 cars per capita (Davis, Diegel and Boundy 2013).

Local travel miles is a measure of all local miles (generally one hundred miles or less from DR) traveled by DRVC users (Figure 6). Each DRVC vehicle has a mileage log that must be completed during each trip for billing purposes. The total number of miles driven was divided by the number of DRVC users to get a per capita rate. For 2013 and 2014, the community drove an average of 899 miles $(1,447 \mathrm{~km})$ per user, per year. Compared to the average American's 9,455 miles (15,216km), according to the Transportation

\footnotetext{
${ }^{8}$ Sixty seven DRVC users is greater than the total number of community members. This number reflects the fact that DRVC vehicles are used by long term residents or those exploring community membership as well as occasionally by members of two neighboring intentional communities, Red Earth Farms and Sandhill Farm, and several on-site business accounts.
} 
Energy Data Book, this puts DR at under 10\% the usage of the average person in the US, or just over a $90 \%$ reduction on average in local vehicle travel miles (Davis, Diegel and Boundy 2013). ${ }^{9}$

\section{Number of Vehicles Per Capita}

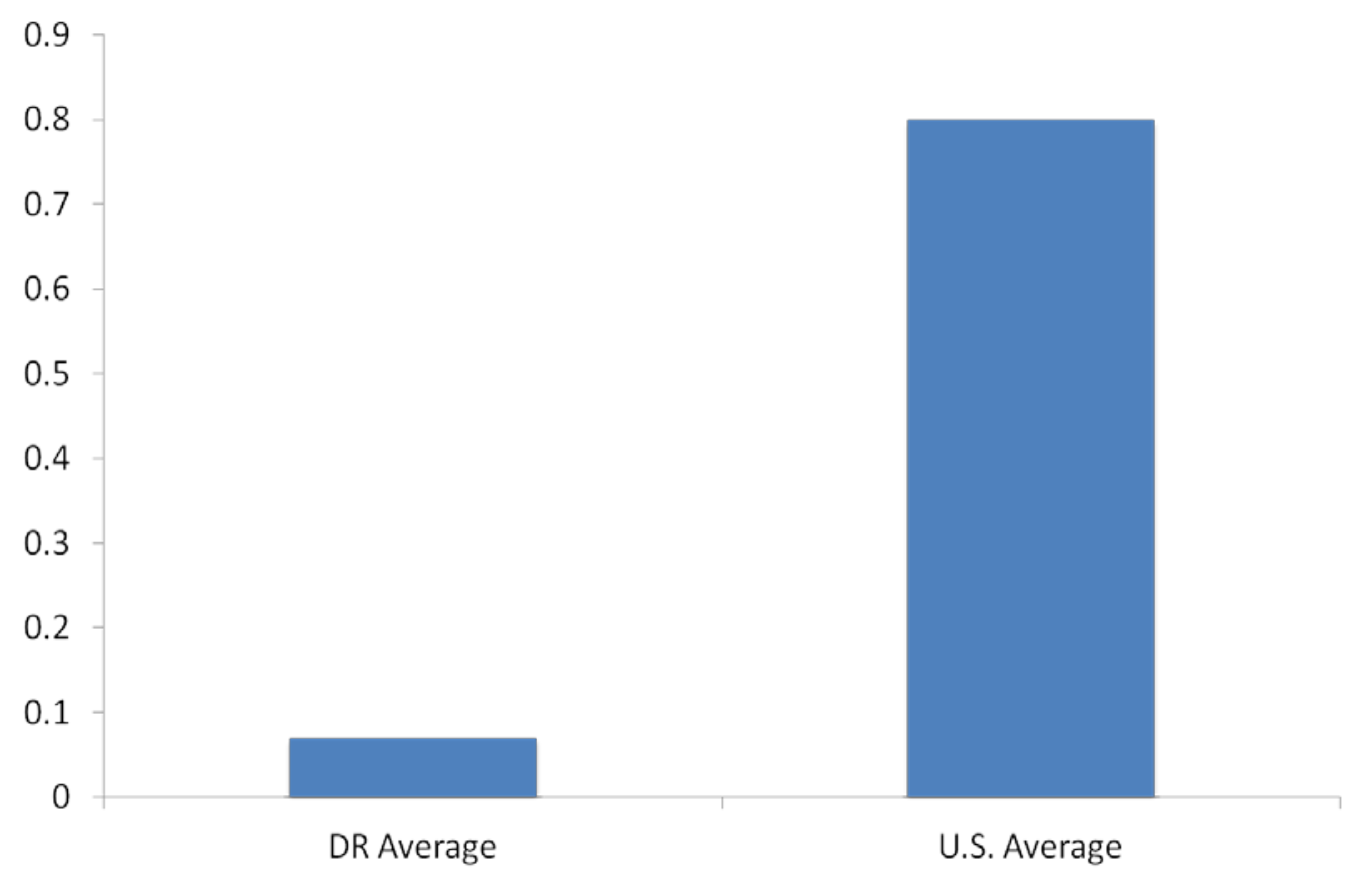

Figure 5: Dancing Rabbit vehicles per capita. Source: K. Brooke Jones 2015.

\footnotetext{
${ }^{9}$ This underestimates total travel for DR members as it does not include long distance travel which occurs outside of DRVC such as when community members visit family in other parts of the country. However, it is important to note that much of this long distance travel occurs via various forms of mass or public transit and this will not add significantly to our mileage totals. We are currently working to measure long distance travel in order to have a more accurate picture of travel at DR to present with future results.
} 


\section{Local Vehicle Miles Per Year Per Capita*}

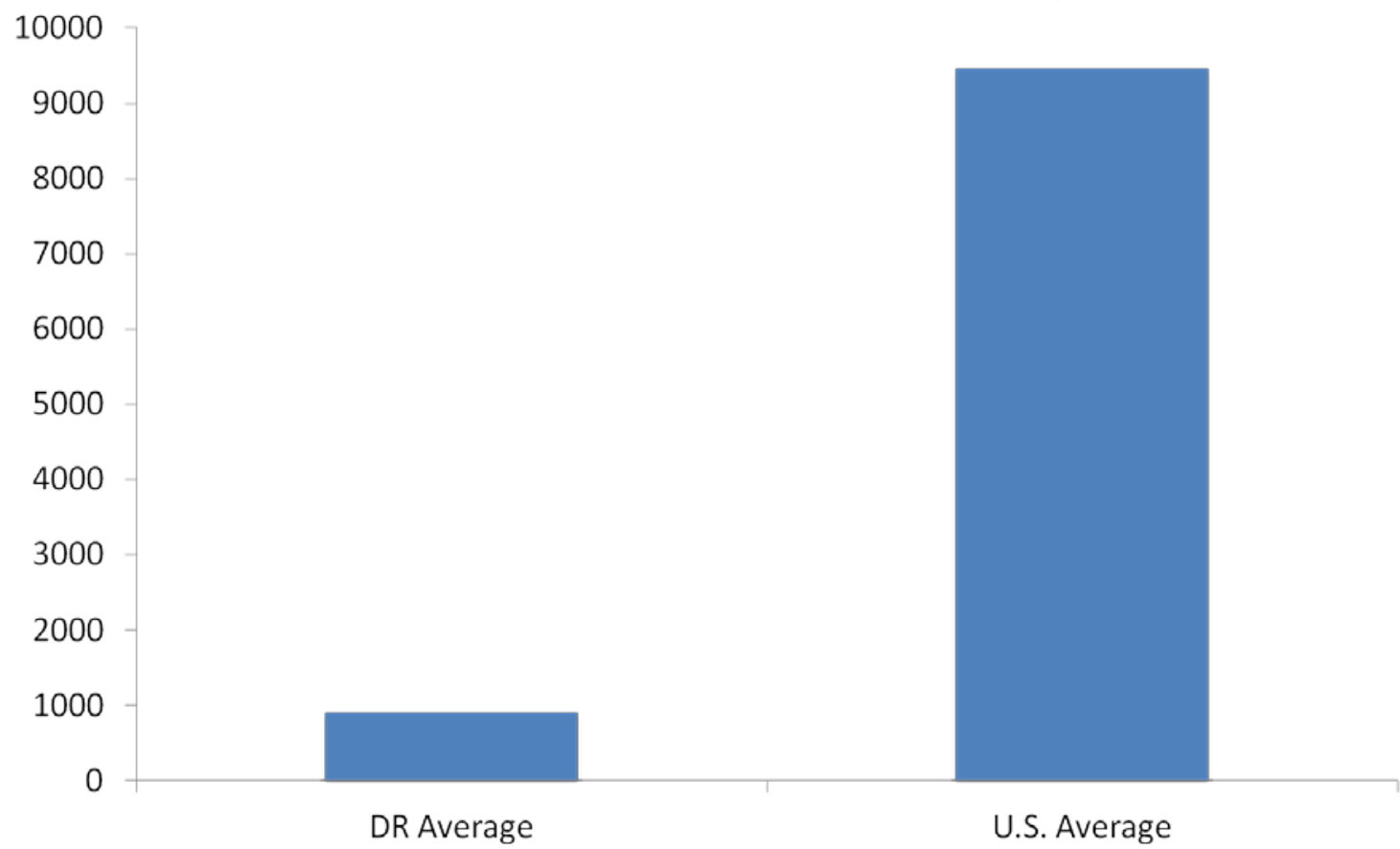

Figure 6: Dancing Rabbit local vehicle travel miles. Source: K. Brooke Jones 2015.

Vehicle fuel consumption is a measure of total gallons of fuel used for transportation within the DRVC, measured in gallons of fuel per capita (Figure 7). This indicator has three elements: petroleum gasoline consumption, biodiesel consumption, and total fuel consumption in gallons per person. All DRVC vehicles have been converted to run on locally available biodiesel, but more petroleum gasoline is used by volume because of the lengthy cold season when biodiesel gels and does not function for vehicle fuel. In addition, biodiesel is increasingly difficult to source in the area and residents argue that it is not particularly energy efficient to produce, so use of this fuel is decreasing within DRVC. Again, DRVC accounting records provided a wealth of information regarding fuel purchases. We took the amount of fuel consumed according to DRVC records and divided by the average number of DRVC users for 2013 and 2014 in order to calculate the per person rate of consumption of 28 total gallons of fuel per person, per year-18 petroleum gasoline and 10 biodiesel. Compared to the average American's 466 gallons per person per year, our figures put DR members at $6 \%$ of the average American's total fuel use, and $4 \%$ of petroleum fuel use (Davis, Diegel, and Boundy, 2013). 


\section{Vehicle Fuel (gallons/per capita/year)}

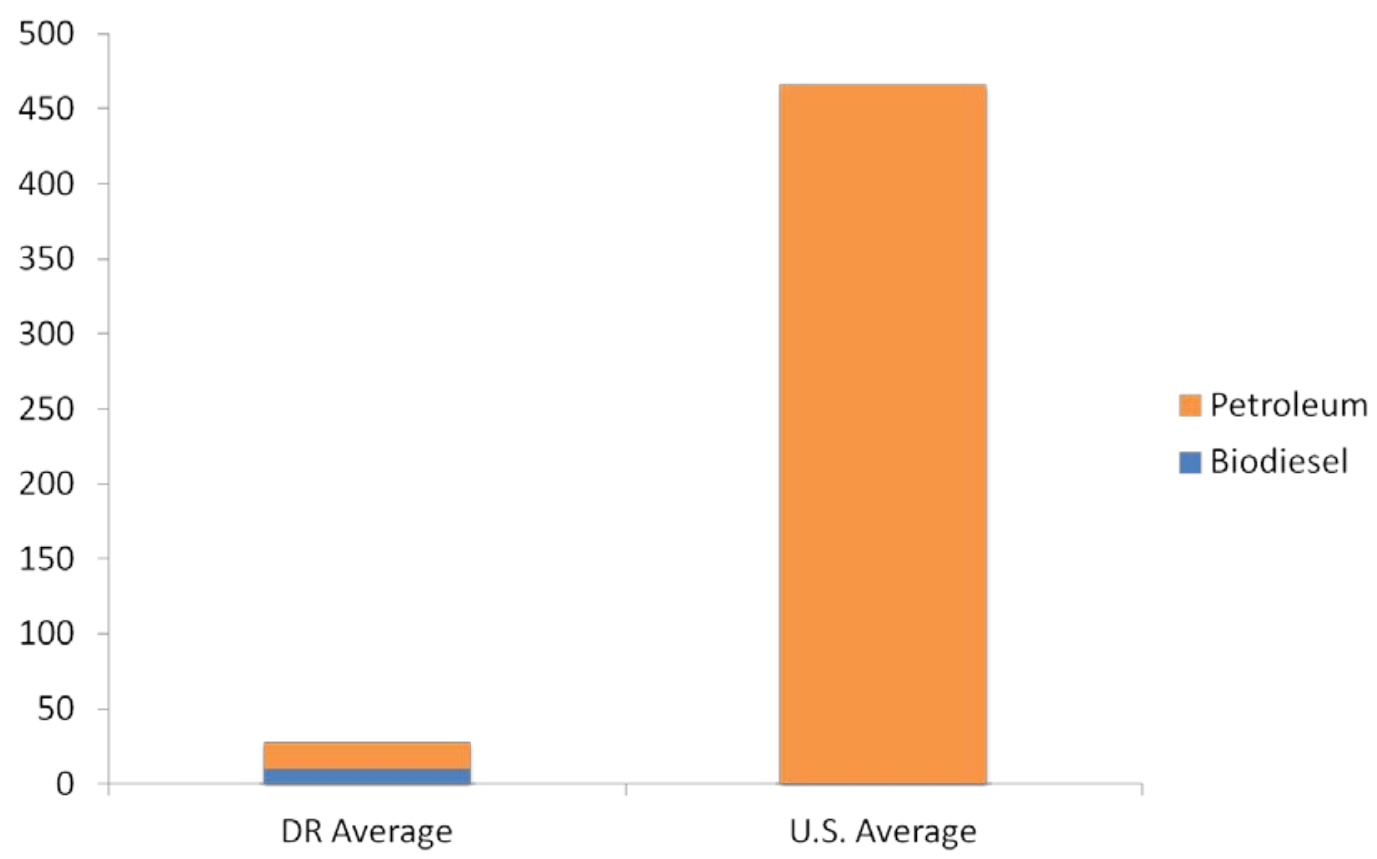

Figure 7: Dancing Rabbit vehicles fuel consumption. Source: K. Brooke Jones 2015.

Propane is the only natural gas used in the community, primarily for cooking (Figure 8). The natural gas indicator monitors the amount of propane used per person, based on data from MFA Oil records, the local propane company that trucks in gas to fill stationary tanks. Individual reports from other propane users who fill their own tanks as needed are also included. Data collected accounts for roughly $80 \%$ of the community. The amount of propane calculated per year was divided by the number of people served by each propane tank in order to calculate a per person usage rate. This rate was converted to therms, a unit of heat equivalent to 100,000 BTUs, in order to be comparable to US data. According to our data, community members use 22 therms of propane gas per person, per year, equivalent to approximately $5 \%$ of the average American's use of 417 therms of natural gas (United States Energy Information Administration 2006).

Electricity consumption includes the total amount of electricity used by DR members as monitored through the Better Energy for Dancing Rabbit (or BEDR) system, measured as the average annual residential electricity consumption per capita in kilowatt hours (Figure 9). BEDR is a power cooperative within DR which operates 25 kilowatts of solar panels and is connected to the local utility grid. BEDR provides power to homes or buildings in the community which desire to connect to its network for a monthly fee and a per kilowatt charge. DR's covenants allow for grid connection so long as they export twice as much renewable energy to the grid as they take from it. ${ }^{10}$ Based on 2012 through 2014 data, the average person at DR

\footnotetext{
${ }^{10}$ In 2012, the community put 3.5 times as much energy produced from renewables back into the grid as they took from it. Since 2012, the community has not met its covenant, although it has put more into the grid than it has drawn from it every year. The community is currently holding an ongoing conversation about how to get back in compliance with their covenant.
} 
consumes $744 \mathrm{kWh}$ per person per year. That is 18\% of the average American's 4,168 kWh per person per year, according to the United States Energy Information Administration (2013). It should be noted that this $82 \%$ reduction in the rate of electricity consumption was achieved by people who are largely providing their own energy through renewable sources, plus exporting more renewable energy back to the grid than was drawn from it. Business electricity use is also counted in the DR electricity usage numbers whereas it is not for the average American. In addition, our analysis does not include those community members who choose to be electricity free so our numbers may actually overstate electricity use.

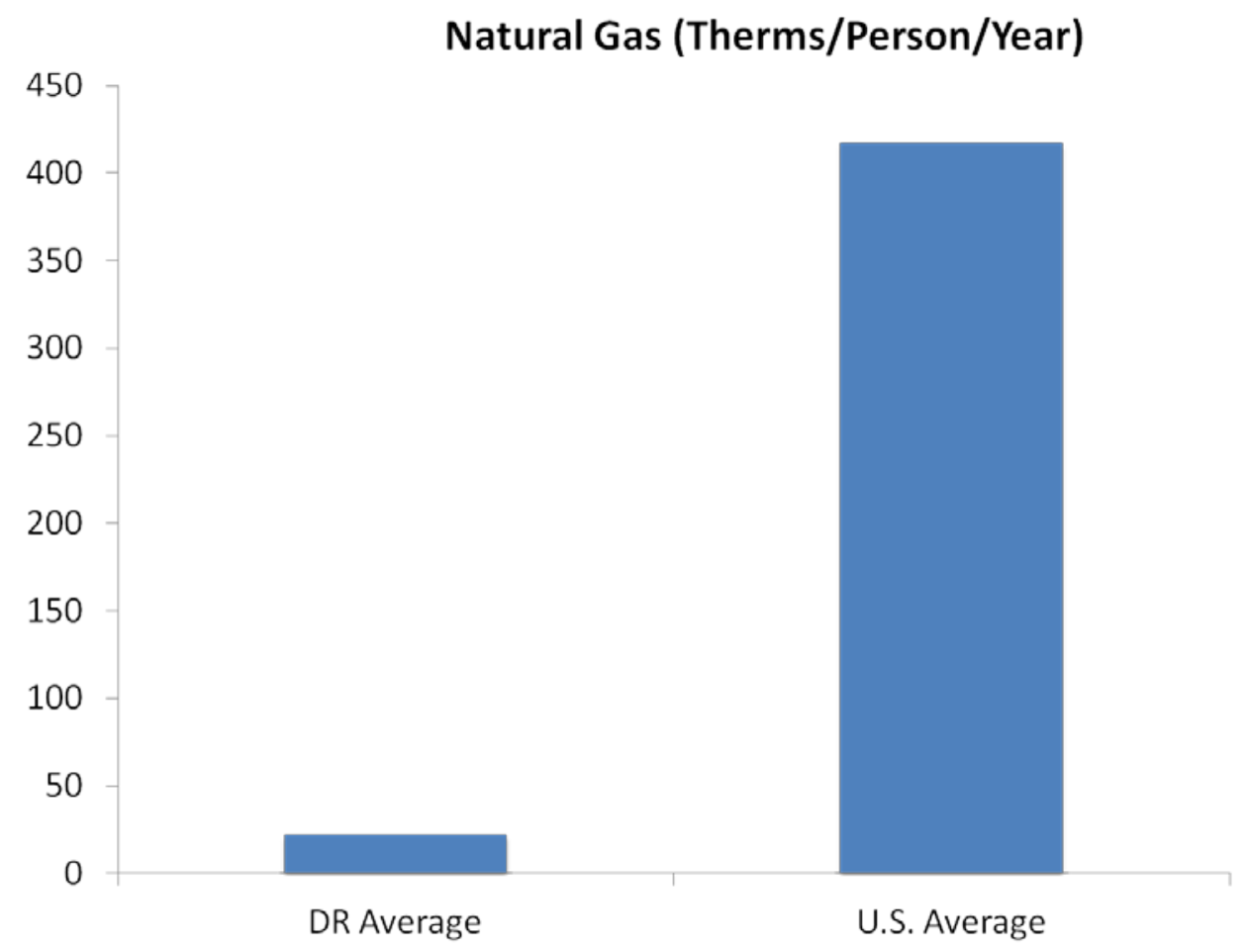

Figure 8: Dancing Rabbit natural gas consumption. Source: K. Brooke Jones 2015.

Water use at DR was measured by calculating figures for both public water supply and rainwater catchment (self-supply). Public water use is a measure of per capita water use by the community according to the Scotland County Water District's records. County water use is measured in total volume (gallons) of water piped in, divided by the number of person years ${ }^{11}$ for a given year to reach the per capita rate. County records show the community used an average of 7 gallons (32 litres) of public water per capita, per day on average in 2013 and 2014 (Scotland County Water Supply Office 2013).

\footnotetext{
${ }^{11}$ Person years is a number determined through DR's accounting system by calculating the number of people who paid the village-wide fees required for anyone on-site for a week or more and dividing that into a portion of a year. Because there are many short term visitors and interns at DR, this calculation is used to account for all segments of the population using local utilities and thus generate a more accurate measure of per capita consumption.
} 


\section{Electricity (kWh/person/year)}

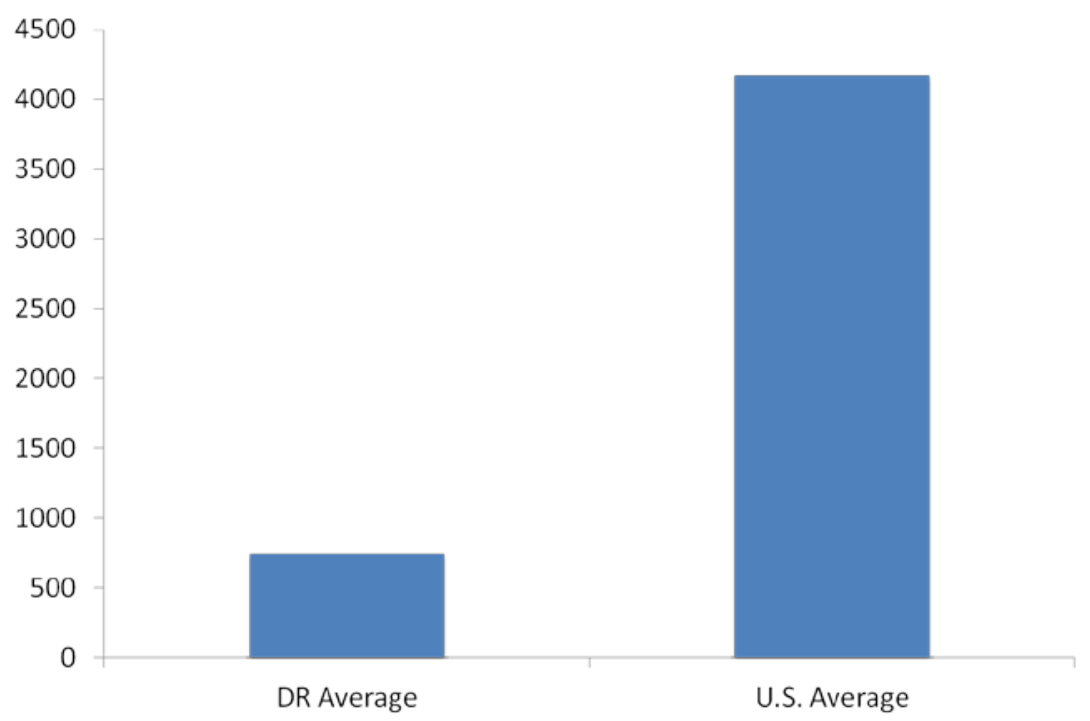

Figure 9: Dancing Rabbit electricity consumption. Source: K. Brooke Jones 2015.

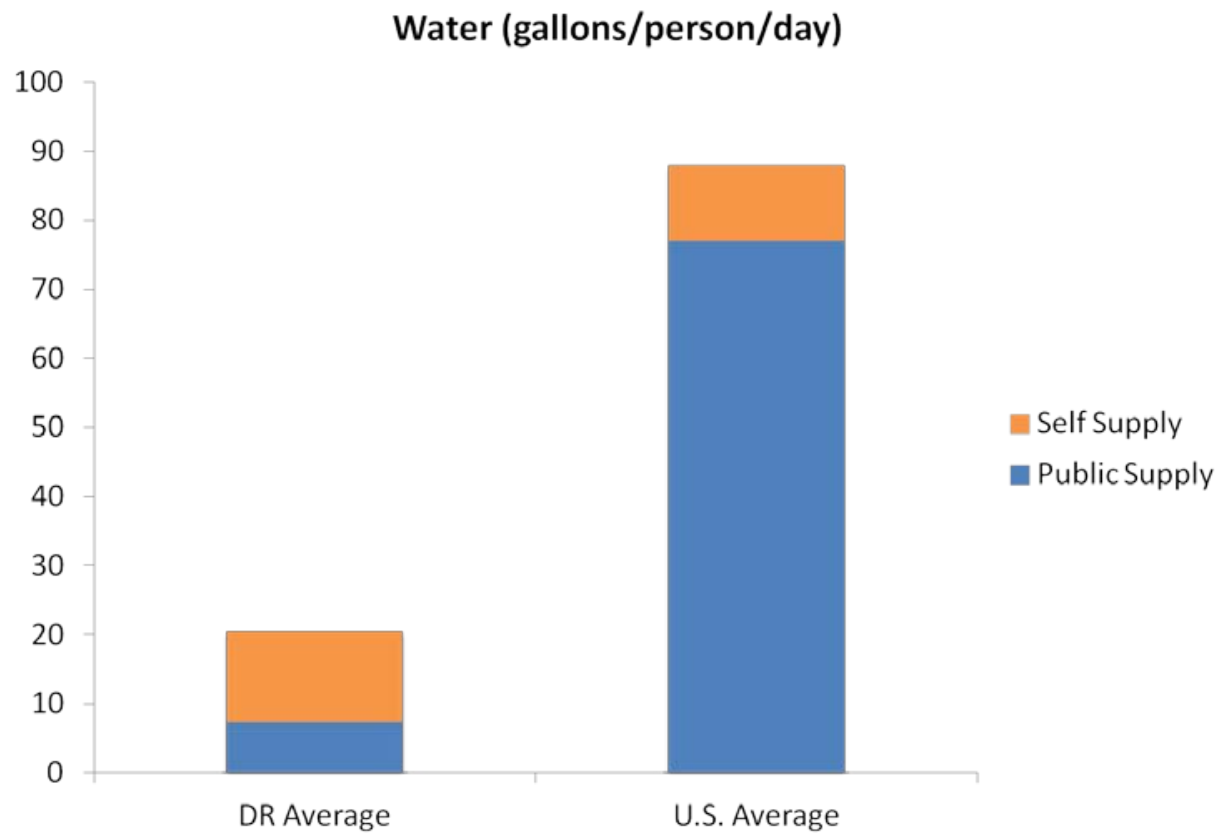

Figure 10: Dancing Rabbit water use. Source: K. Brooke Jones 2015. 
Since many of the buildings at DR incorporate rainwater catchment systems for residential use into their designs, the figure in the paragraph above does not reflect total water use. Rainwater use is estimated due to current lack of monitoring systems on rainwater catchment barrels. To estimate rainwater catchment at DR, we started by calculating total potential captured rainfall based on a rainwater catchment calculation which uses the square footage of building roofs and amount of rainfall for the year. The rainwater calculation also included a factor of $50 \%$ to $80 \%$ to correct for systems that we knew were not functioning at full capacity. For 2013 and 2014, an estimate of 13 gallons (59 litres) of rainwater were used per capita per day.

Total per capita daily water use at DR is a combination of the previous two indicators, public supply and rainwater catchment. For 2013 and 2014, a total of 20 estimated gallons (91 litres) of water was used per person year, per day. This puts DR at 23\% of the use rates of the average American's 88 gallons (400 litres) and $9 \%$ of the public, municipal water use according to the US Geological Survey's estimates (Kenny et al. 2014). By these calculations, DR gets $35 \%$ of their water from the public supply and $65 \%$ from self-supplied water compared to the average American community where $87 \%$ is from public supply and $13 \%$ is selfsupplied. It should be noted that the water use numbers for DR include business, domestic, outdoor, and agriculture usage whereas the numbers we compare against are for indoor and outdoor residential use only. Thus, the figures for DR are likely a significant overstatement of water use when compared with average figures for the mainstream population.

In order to assess quality of life we did a series of in person interviews with community members in which we asked questions regarding their happiness and well-being. Two quantitative, Likert scaled questions are included in the interview protocols. When asked, "How happy are you with life at Dancing Rabbit right now?" $81 \%$ of participants reported a level of 7 or above, on a scale from 1 to 10 with 1 being least happy and 10 being most happy. When asked, "Do you think Dancing Rabbit is a good place to live?" $88 \%$ of participants responded with a 4 or 5 on the following scale: $1=$ not at all a good place to live, $2=$ a somewhat good place to live, $3=$ neutral, $4=$ good, and $5=$ extremely good. These results are especially interesting given the interviews were completed during a time of exceptionally high tensions within the community surrounding a contentious process of reordering the community's capital expenditure budgets. Our quality of life questions were drawn from a survey conducted by Sustainable Seattle as part of their Indicators of Sustainable Community 1998 project (Palmer 2004[1998]). Responses of DR members were on par with responses from Seattle residents suggesting that DR members have a perceived high quality of life despite arranging their lives around attempts to significantly decrease resource use.

Our qualitative data from interviews with DR members indicate that perceived quality of life is multidimensional; extended answers to our open-ended questions about this topic were far from straightforward. For example, after giving a happiness-with-life at DR score of 8 out of 10, one participant said the following:

My current state of inner harmony with myself is not yet at a point where I am as happy as I could be. There's still too much internal arguing and when I choose to do one thing there's a voice in me telling me I should be doing something else and that makes it hard to just be like, YES, I am ecstatically happy about what I am doing here at Dancing Rabbit. I think that's more where it is, but Dancing Rabbit is giving me the container to look at that and start to actually move into shifting and that's pretty cool. ${ }^{12}$

This participant went on to discuss a variety of issues that present challenges and satisfaction in the context of the community. These issues included parenting in a novel environment, social relationships with other community members and support from them, conflict resolution procedures within the community, and building a business within the community. Our analysis of our qualitative data on quality of life at DR is as yet incomplete. However, our preliminary analysis supports the quantitative data presented above while

\footnotetext{
${ }^{12}$ Interview with DR community member, summer 2013.
} 
demonstrating that quality of life is a complex construct that each individual community member perceives and experiences in unique ways.

Our data on quality of life at DR are supplemented by data from a recent, large scale survey of intentional communities. Some of our colleagues at SUNY Binghamton and the Norwegian Institute of Public Health surveyed the members of almost 200 intentional communities around the world, including DR. In their survey they asked a large set of intentional community members questions that were previously presented to people from other demographics in a variety of other studies. Collectively, their results demonstrate that intentional community members lead lives that are highly meaningful and satisfying relative to a variety of other segments of the public and that their lives improved after they joined their respective intentional communities (MacDonald personal communication Nes personal communication) (Figures 11, 12, and 13).

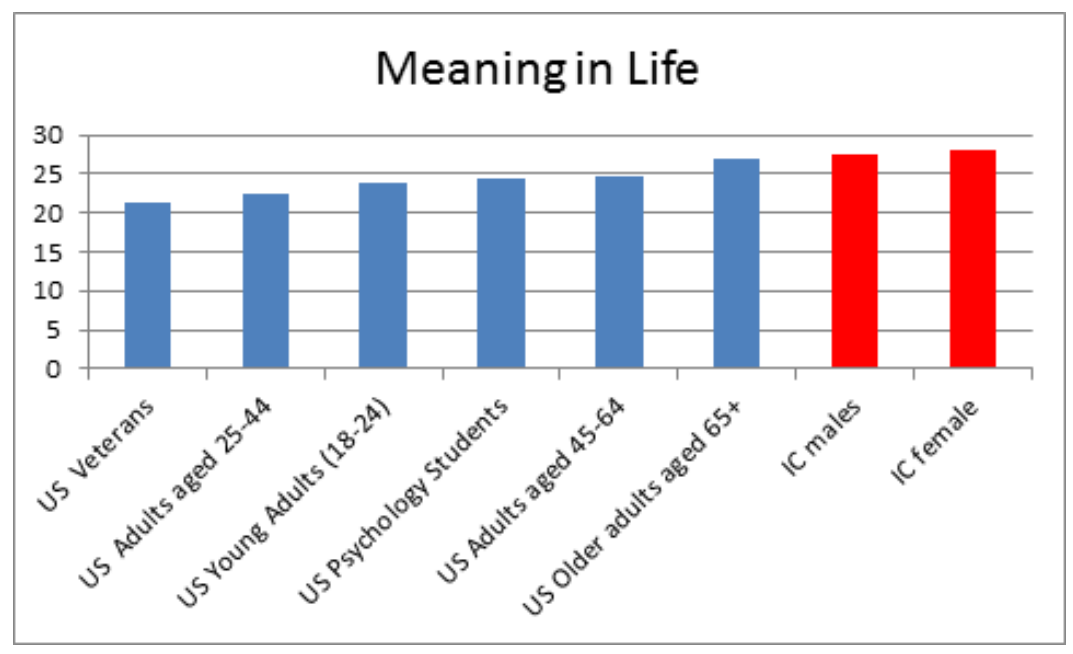

Figure 11: Meaning in life for intentional community members. Source: Ragnhild Bang Nes 2015.

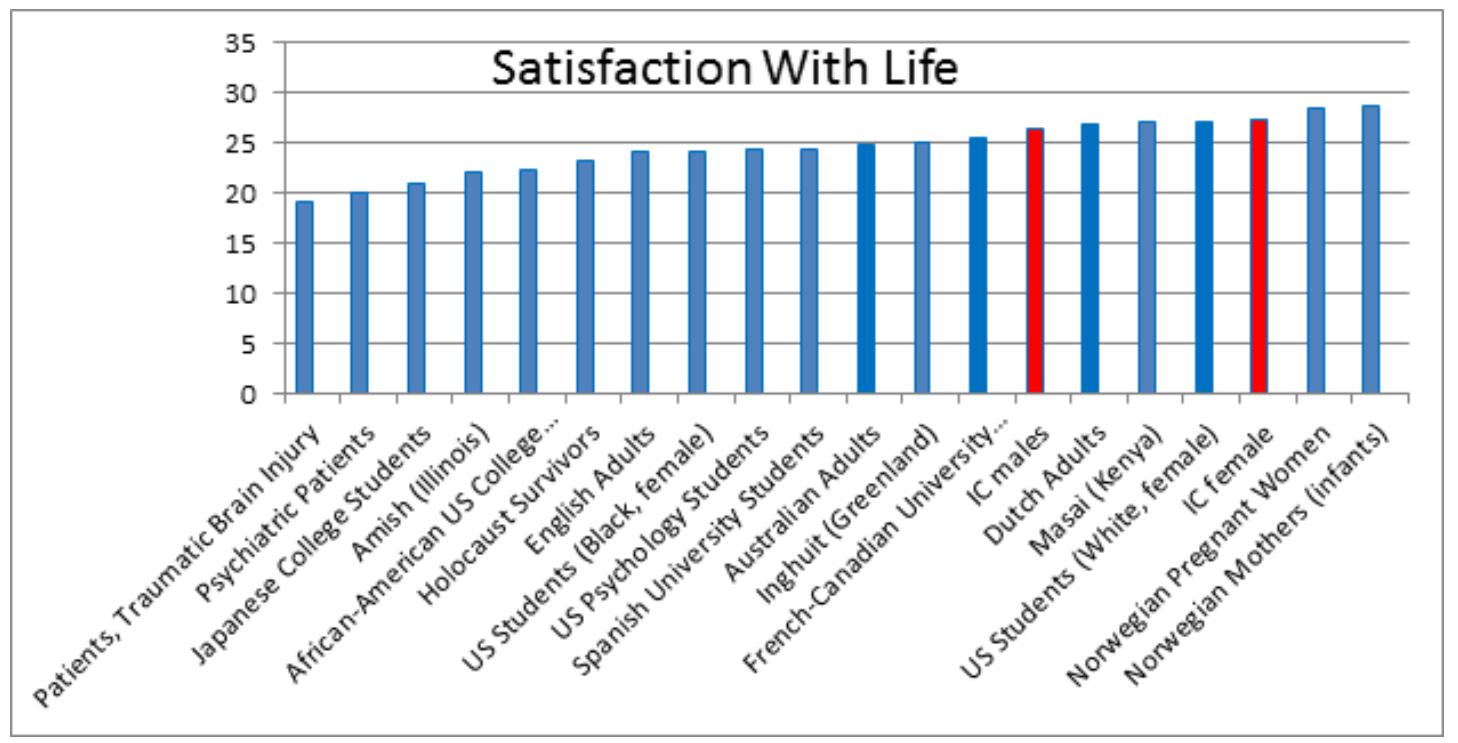

Figure 12: Satisfaction with life for intentional community members. Source: Ragnhild Bang Nes 2015. 


\section{Life Since Joining Community}

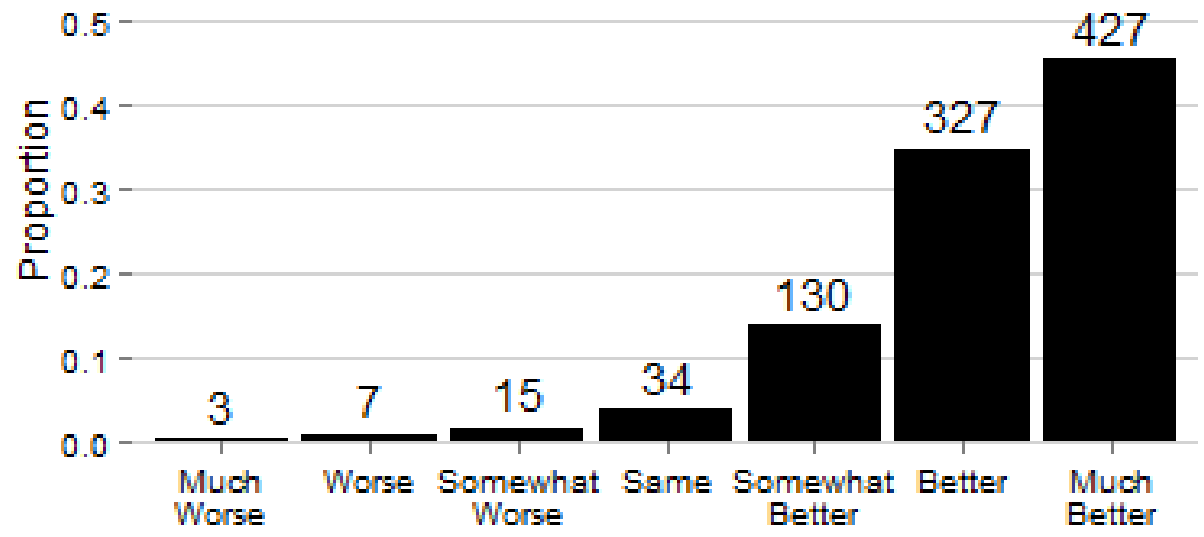

Figure 13: Quality of life since joining for intentional community members. Source: Ian MacDonald 2015.

When we parse out the data specifically collected from members of DR, we see that DR members fall distinctly within the range of life satisfaction of intentional community members in general, as depicted via the red dot on the graph below.

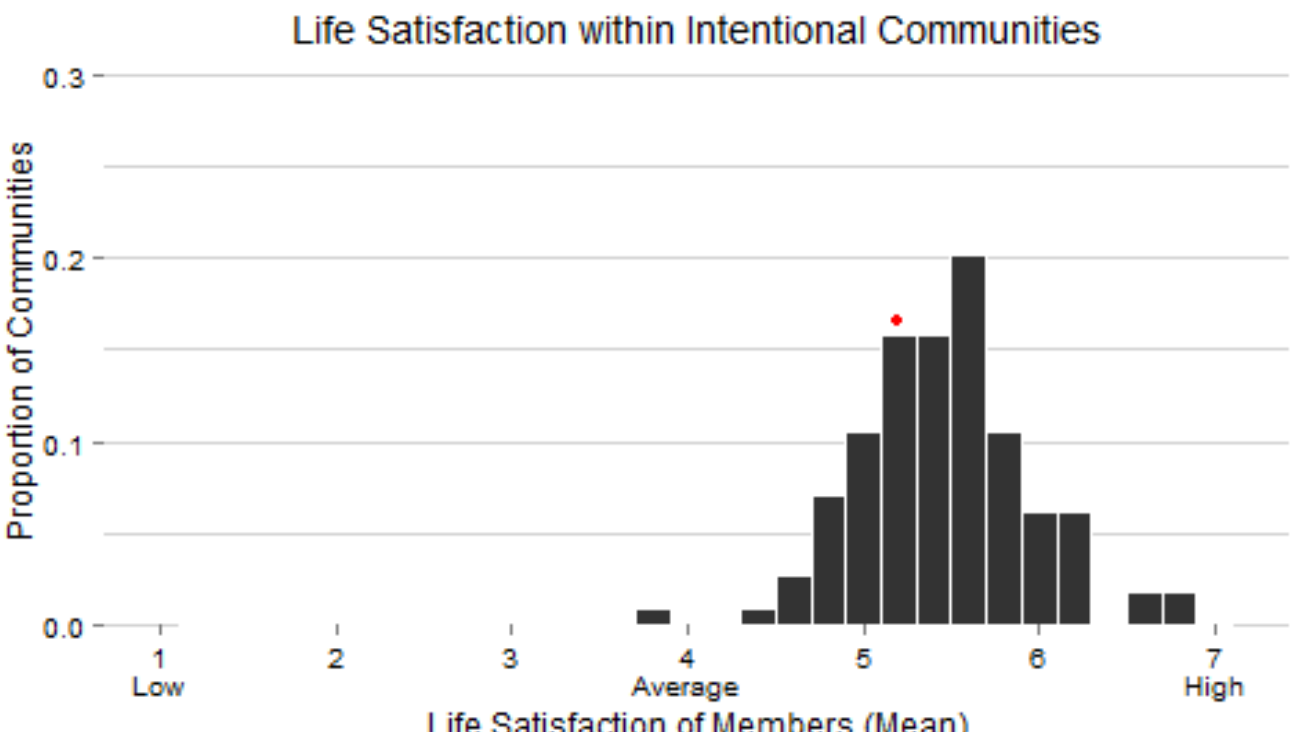

Life Satisfaction of Members (Mean)

Figure 15: Life satisfaction for intentional communities (with Dancing Rabbit indicated by red dot). Source: Ian MacDonald 2015. 
Overall, the results of our research show the community is reducing consumption significantly, thereby partially mitigating some of the negative social and ecological impacts of global, industrial supply chains, while also maintaining high levels of perceived happiness and satisfaction with life. Overall, DR members are as happy as or happier than many other segments of the public, despite living on approximately $10 \%$ of the resources used by the average American in a number of key consumption areas (see Jones 2014a,b,c). These numbers strongly suggest that material degrowth is achievable without significantly sacrificing quality of life. DR's efforts demonstrate that it is possible to maintain happiness and modest resource use and could provide models for segments of the public that are interested in reducing their material consumption.

\section{Conclusion: translating to broader theory and practice}

In line with participatory action research methodology and our desire to produce results that are useful to the DR community and its nonprofit 501(c)3 research and education organization, we continually share our results with the community. Following formal presentations to the community based on ongoing data collection and analysis, the Executive Director of DR's nonprofit organization incorporated the results of our data analysis into a nationwide speaking tour and accompanying workshops that focused on DR as an example of positive social transformation for justice and sustainability. ${ }^{13}$ Those engagements reached approximately 2,700 people in thirty communities, organizations, and institutions of higher learning with the goal of empowering people to initiate transition discourses and practices in their existing communities.

Clearly, the challenge of transitioning toward degrowth societies cannot be fully addressed by everyone joining a rural ecovillage; such an approach could not accommodate large populations of people for a variety of reasons. However, scholar-activists can facilitate ecovillage experiments through collaborative critical analysis and they can support participants in these experiments as they publicize and promote their endeavors in efforts to inform and motivate a broad array of actors and initiatives seeking more sustainable models. Different components of these experiments can be translated to different contexts; ecovillage innovations in cooperative housing arrangements, land trust-based community organizing and commons stewardship, natural and green building techniques, agroecology-based organic food production, community currencies, and general strategies for reduced consumption are all applicable in the context of existing neighborhoods and municipalities. One of my goals as an activist-researcher is to help translate from the particular ecovillage as a living laboratory for sustainability to more broadly applicable theory and practice.

A growing number of scholars are collaborating with advocates and practitioners of various transition discourses and orienting their research and engagement activities around normative imperatives of justice and environmental sustainability (for example see Escobar 2008; Gibson-Graham 2006; Martinez-Alier et al. 2014; see also in this Section, Bogadóttir and Olsen 2017; Demmer and Hummel 2017; DeVore 2017; Foster 2017 and Hornborg 2017). The collaborative research I have described here is part of my broader personal and professional engagement aimed at using scholarly research and critical analysis to further societal transitions toward justice and sustainability. I aim to use scientific research methods and critical analysis to help communities like DR become more effective at achieving their goals, while simultaneously using my position within realms of institutional power to raise awareness about and increase the legitimacy of the endeavors of these transition practitioners. As my co-author and I argue in our introduction to a recent Special Section of the Journal of Political Ecology (Towards a political ecology of applied anthropology) "any applied anthropology that engages, documents, promotes, and supports cultural diversity, social justice and environmental sustainability is just" (Veteto and Lockyer 2015: 357). In this context, ongoing engagement with advocates and practitioners of degrowth, commons, and intentional communities 'transition discourses' presents an opportunity to cultivate a morally-grounded, justice- and sustainability-oriented applied research paradigm. Simultaneously, such engagement opens up spaces to analyze processes of cultural change and transition that are of fundamental interest to social and behavioral scientists and of direct import to policy makers concerned with the sustainable use and conservation of natural resources.

\footnotetext{
${ }^{13}$ See http://www.dancingrabbit.org/speakingtour
} 
Like many other intentional communities, DR is defined by a purpose-driven existence, one that is oriented around the design of socio-cultural patterns aimed at sustainable balance between ecosystems and social systems. For social scientists, these 'utopian' communities serve as natural laboratories where deliberate design for sustainability is the starting point, and where ongoing attention to resource use and effective environmental stewardship shape the cultural context for human behavior, as manifested in explicitly stated community norms, rules, and ritual activities. Collaboration and engagement on the part of scholar-activists allow our skills of critical analysis and our desire to identify what does and does not work in the transition to resilient, sustainable societies to converge in synergistic ways with the interests of those we study. Such engagement aligns well with suggestions that "degrowth be understood as representing a form of 'activist-led science,' within which a movement for social and political change coalesces with the academic study of economic, social and environmental change in creative ways" (Whitehead 2013:143; see also D'Alisa and Kallis 2015 and Ravetz and Funtowicz 1999; and on 'post-normal science'). If, as Latouche states, "...de-growth is conceivable only in a de-growth society, or in other words within the framework of a system based upon a different logic" (2009: 8), then in places like DR, we seem to have found our muse.

\section{References}

Alden Wiley, L. 2011. 'The law is to blame': the vulnerable status of common property rights in Sub-Saharan Africa. Development and Change 42(3): 733-757.

Bogadóttir, R. and E.S. Olsen. 2016. Making degrowth locally meaningful: the case of the Faroese grindadráp. Journal of Political Ecology 304-518.

Bollier, D. 2014. Think like a commoner: a short introduction to the life of the commons. Gabriola Island, BC: New Society Publishers.

Burger, J., E. Ostrom, R. Norgaard, D. Policansky and B.D. Goldstein (eds.). 2001. Protecting the commons: a framework for resource management in the Americas. Washington, DC: Island Press.

Chambers, R. 1997. Whose reality counts? Putting the first last. London: Intermediate Technology Publications. Ch.1\&2.

D'Alisa, G. and G. Kallis 2015. Post-normal science. In G. D'Alisa, F. Demaria and G. Kallis (eds.) Degrowth: a vocabulary for a new era. New York: Routledge.

Dancing Rabbit Ecovillage. 2015a. Dancing Rabbit mission statement. [accessed 15 October 2015]. http://www.dancingrabbit.org/about-dancing-rabbit-ecovillage/vision/mission-statement/

Dancing Rabbit Ecovillage. 2015b. Dancing Rabbit land trust. [accessed 15 October 2015]. http://www.dancingrabbit.org/about-dancing-rabbit-ecovillage/our-land/dancing-rabbit-land-trust/

Dancing Rabbit Ecovillage. 2015c. Ecological covenants. [accessed 15 October 2015]. http://www.dancingrabbit.org/about-dancing-rabbit-ecovillage/vision/ecological-covenants/

Dancing Rabbit Ecovillage. 2015d. Sustainability guidelines. [accessed 15 October 2015]. http://www.dancingrabbit.org/about-dancing-rabbit-ecovillage/vision/sustainability-guidelines/

Davis, S., S.W. Diegel, and R.G. Boundy. 2013. Transportation energy data book: Edition 32. ORNL-5198 Center for Transportation Analysis, Energy and Transportation Science Division. Oak Ridge, TN: Oak Ridge National laboratory. [accessed 15 April 2014]. http://cta.ornl.gov/data/

Demmer, U. and A. Hummel. 2017. Degrowth, anthropology, and activist research: the ontological politics of science. Journal of Political Ecology 24: 610-622.

DeVore, J. 2017. Trees and springs as social property: A perspective on degrowth and redistributive democracy from a Brazilian squatter community. Journal of Political Ecology 24: 644-666.

Dolšak, N. and E. Ostrom. 2003. The commons in the new millennium: challenges and adaptations. Cambridge: MIT Press.

Donahue, B. 1999. Reclaiming the commons: community farms and forests in a New England town. New Haven, CT: Yale University Press. 
Dwinell, A. and M. Olivera. 2014. The water is ours damn it! Water commoning in Bolivia. Community Development Journal 49(SI): i44-i52.

Ervin A.M. 2000. Applied anthropology: tools and perspectives for contemporary practice. Boston: Allyn and Bacon.

Escobar, A. 2008. Territories of difference: place, movements, life, redes. Durham, NC: Duke University Press.

Escobar, A. 2015. Degrowth, postdevelopment, and transitions: a preliminary conversation. Sustainability Science 10(3): 451-462.

Fellowship for Intentional Community. 2015a. Welcome to the Fellowship for Intentional Community. [accessed on 15 November 2015].

Fellowship for Intentional Community. 2015b. What is an "intentional community"? Communities: Life in Cooperative Culture 168(Fall): 6.

Fellowship for Intentional Community. 2015c. Communities Directory. [accessed on 15 November 2015].

Foster, K. 2017. Work ethic and degrowth in a changing Atlantic Canada. Journal of Political Ecology 24: 633-643.

Gibson-Graham, J.K. 2006. A postcapitalist politics. Minneapolis, MN: University of Minnesota Press.

Hardin, G. 1968. The tragedy of the commons. Science 162(3859): 1243-1248.

Hornborg, A. 2017. How to turn an ocean liner: proposal for voluntary degrowth by redesigning money for sustainability, justice, and resilience. Journal of Political Ecology 24: 623-632.

Jackson, T. 2009. Prosperity without growth: economics for a finite planet. London: Earthscan.

Jones, K.B. 2014a. Toward sustainability: assessing progress at Dancing Rabbit Ecovillage. Master's thesis, University of North Texas.

Jones, K.B. 2014b. Trailblazing sustainability: how an ecovillage in northeastern Missouri is creating sustainable culture in community. Paper presented at the 74th annual meeting of the Society for Applied Anthropology. Albuquerque, NM, March 19, 2014.

Jones, K.B. 2014c. Faith in sustainability: how Dancing Rabbit Ecovillage is creating sustainable culture in community. Paper presented at the Communal Studies Association annual conference. Amana, IA, October 11, 2014.

Kenny, J.F., N.L. Barber, S.S. Hutson, K.S. Linsey, J.K. Lovelace, and M.A. Maupin. 2014. Estimated use of water in the United States in 2010. U.S. Geological Survey Circular 1405, p. 20-21. [accessed 20 February 2016].

Kirby, A. 2003. Redefining social and ecological relations at the ecovillage at Ithaca: a case study. Journal of Environmental Psychology 23: 323-332.

Kloppenburg, J. 2010. Impeding dispossession, enabling repossession: biological open source and the recovery of seed sovereignty. Journal of Agrarian Change 10(3): 367-388.

Katherine Lambert-Pennington 2010. Practicing what we preach: the possibilities of participatory action research within faith-based organizations. NAPA Bulletin 33: 143-160

LeCompte M.D. and J.J. Schensul, 2010. Designing and conducting ethnographic research: an introduction New York: Altamira.

Latouche, S. 2009. Farewell to growth. Malden: Polity Press.

Levitas, R. 2013. Utopia as method: the imaginary reconstitution of society. New York: Palgrave Macmillan.

Litfin, K.T. 2013. Ecovillages: lessons for sustainable community. Malden, MA: Polity Press.

Lockyer, J. 2007. Sustainability and utopianism: an ethnography of cultural critique in contemporary intentional communities. Ph.D. dissertation, University of Georgia: Department of Anthropology.

Lockyer, J. 2010a. Intentional communities and sustainability. Communal Societies 30(1): 17-30. 
Lockyer, J. 2010a. Intentional community carbon reduction and climate change action: from ecovillages to transition towns. In M. Peters, S. Fudge, and T. Jackson (eds.) Low carbon communities: imaginative approaches to combating climate change locally. UK: Edward Elgar. Pp 197-215.

Lockyer, J. and J.R. Veteto. 2012. Ecovillages. In S.G. Beavis, M. Dougherty, and T. Gonzales (eds.) The encyclopedia of sustainability: vol. 8. The Americas and Oceania: assessing sustainability. Great Barrington, MA: Berkshire Publishing. Pp 92-95.

Lockyer, J. and J.R. Veteto. 2013. Environmental anthropology engaging ecotopia: bioregionalism, permaculture, and ecovillages. New York: Berghahn Books.

Martinez-Alier, J., I. Anguelovski, P. Bond, D. Del Bene, F. Demaria, J.F. Gerber, L. Greyl, W. Haas, H. Healy, V. Marín-Burgos, G. Ojo, M. Porto, L. Rijnhout, B. Rodríguez-Labajos, J. Spangenberg, L. Temper, R. Warlenius and I. Yánez. 2014. Between activism and science: grassroots concepts for sustainability coined by Environmental Justice Organizations. Journal of Political Ecology 21: 19-60.

McCay, B. and J.M. Acheson (ed.). 1987. The question of the commons: the culture and ecology of communal resources. Tucson, AZ: University of Arizona Press.

Metcalf, B. 2004. The Findhorn book of community living. Forres, Scotland: Findhorn Press.

Mulder, K., R. Constanza, and J. Erickson. 2006. The contribution of built, human, social and natural capital to quality of life in intentional and unintentional communities. Ecological Economics 59: 13-23.

Nonini, D.M. (ed.). 2008. The global idea of 'the commons'. New York: Berghahn Books.

North, P. 2005. Scaling alternative economic practices? Some lessons from alternative currencies. Transactions of the Institute of British Geographers 30: 221-233.

Ostrom, E. T. Dietz, N. Dolšak, P.C. Stern, S. Stonich, and E.U. Weber. 2002. The drama of the commons. Washington, DC: National Academy Press.

Palmer, K. (ed). 2004[1998]. Sustainable Seattle: indicators of sustainable community report. A status report on long-term cultural, economic, and environmental health for Seattle/King County. Seattle: Sustainable Seattle.

Paulson, S. 2017. Degrowth: culture, power and change. Journal of Political Ecology 24: 425-448.

Pitzer, D.E. (ed.). 1997a. America's communal utopias. Chapel Hill, NC: The University of North Carolina Press. Preface\&Intro

Pitzer, D.E. 1997b. The new moral world of Robert Owen and New Harmony. In Pitzer, D. (ed.) America's communal utopias. Chapel Hill, NC: The University of North Carolina Press. Preface\&Intro

Ravetz, J. and S. Funtowicz. 1999. Post-normal science - an insight now maturing. Futures 31: 641-646. Researchgate

Rees, W.E. and M. Wackernagel, 1998. Our ecological footprint: reducing human impact on the Earth. Gabriola Island, BC: New Society Publishers.

Sargisson, L. 2012a. Definitions, debates, and conflicts: utopianism, anti-utopianism and anti-antiutopianism. In Sargisson, L. (ed.) Fool's gold? Utopianism in the twenty-first century. New York: Palgrave Macmillan.

Sargisson, L. 2012b. Green intentional communities. In Sargisson, L.(ed.) Fool's gold? Utopianism in the twenty-first century. New York: Palgrave Macmillan.

Scotland County Water Supply Office. 2013. Scotland County Water Supply Account History Listing for 2013. Memphis, MO.

Steffan, W, P.J. Crutzen, and J.R. McNeill. 2007. The Anthropocene: are humans now overwhelming the great forces of nature. AMBIO: A Journal of the Human Environment 36(8): 614-621. Researchgate

Sutton, R.P. 1997. Am American Elysium: The Icarian communities. In Pitzer, D. (ed.) America's communal utopias. Chapel Hill, NC: The University of North Carolina Press. Preface\&Intro

Trainer, T. 2000. Where are we, where do we want to be, and how do we get there? Democracy and Nature 6(2): 267-286. 
Trainer, T. 2002. Debating the significance of the global ecovillage movement: a reply to Takis Fotopoulos. Democracy and Nature 8(1): 143-149.

United States Energy Information Administration. 2006. Residential energy consumption survey. Consumption \& expenditures. Average consumption. Table 8, physical units per household [data file]. Washington DC. [accessed $30 \quad$ December 2015] http://www.eia.gov/consumption/residential/data/2005/index.cfm?view=consumption

United States Energy Information Administration. 2015. 2005 Residential energy consumption survey. $\begin{array}{lllll}\text { Washington } & \text { DC. } & \text { [accessed } & 30 & \text { December }\end{array}$ http://www.eia.gov/consumption/residential/data/2005/c\&e/summary/pdf/tableus8.pdf

United States Environmental Protection Agency. 2013. Municipal solid waste generation, recycling, and disposal in the United States: Facts and figures for 2011. Washington DC. [accessed 15 May 2014]. http://www.epa.gov/epawaste/nonhaz/municipal/msw99.htm.

Van Schyndel Kaspar, D. 2008. Redefining community in the ecovillage. Human Ecology Review 15(1): 1224.

Veteto, J.R. and J. Lockyer. 2015. Applying anthropology to what? Tactical/ethical decisions in an age of global neoliberal imperialism. Journal of Political Ecology 22: 357-367.

Whitehead, M. 2013. Degrowth or regrowth? Environmental Values 22: 141-145. 